\title{
Comparative evaluation of phosphorus accumulation and partitioning in seeds of common bean (Phaseolus vulgaris L.)
}

\author{
Angela Rosa Piergiovanni, Lucia Lioi, Vincenzo Montesano, Giulio Sarli \\ Institute of Biosciences and Bioresources, National Research Council, Bari, Italy
}

\begin{abstract}
There is an increasing attention towards common bean due to its health benefits, prevention to human diseases and as ingredient for functional or fortified foods. Phosphorus, an essential element for plant growth, is mainly stored in seeds as phytic acid (Phy). Phy is negatively associated with mineral bioavailability, but, at the same time, is a natural antioxidant. Accumulation and partitioning of phosphorus were analysed in seeds of ten Italian common bean landraces for three subsequent growing seasons. Some important seed quality traits were also evaluated. For comparative purposes, the landrace harvests of two growing locations were analysed. A wide variation of total and phytic phosphorus contents was recorded among the landraces. Moreover, P accumulation and partitioning between Phy and inorganic $\mathrm{P}$, as well as seed quality traits, resulted strongly affected by growing location. Statistically significant increases of Phy levels were recorded for harvests obtained outside the traditional area of cultivation. These results highlight how the cultivation of a landrace outside of its traditional area will appreciably affect harvest quality.
\end{abstract}

Correspondence: Angela Rosa Piergiovanni, Institute of Biosciences and Bioresources, National Research Council, via Amendola 165/A, 70124 Bari, Italy.

Tel: +39.080 .5583400 .

E-mail: angelarosa.piergiovanni@ibbr.cnr.it

Key words: Genetic resources; Phosphorus; Phytic acid; Seed quality.

Acnowledgments: the authors are grateful to G. Stigliano, N. Fornarelli, and G. Campanella for technical assistance. This research was supported by FEASR Basilicata 2007-2013, Misura 124 HC - Cooperazione per lo sviluppo di nuovi prodotti, processi e tecnologie. Project: Tutela della biodiversità di leguminose tradizionali degli ambienti lucani $e$ valorizzazione mediante innovazioni agronomiche, nutraceutiche e di mercato (Val. Bio. Luc).

Received for publication: 11 October 2016.

Revision received: 17 February 2017.

Accepted for publication: 18 February 2017.

CCopyright A.R. Piergiovanni et al., 2017

Licensee PAGEPress, Italy

Italian Journal of Agronomy 2017; 12:849

doi:10.4081/ija.2017.849

This article is distributed under the terms of the Creative Commons Attribution Noncommercial License (by-nc 4.0) which permits any noncommercial use, distribution, and reproduction in any medium, provided the original author(s) and source are credited.

\section{Introduction}

Grain legumes are an important staple food due to their high nutritional value, long time of conservation of seeds, and low cost. Among legumes, common bean (Phaseolus vulgaris L.) has an important role in the human diet at worldwide level. Its consumption pattern varies dramatically by geographic regions and among cultures, with Latin America being the leading producer and consumer (FAO, 2016). Common bean is an integral part of the Mediterranean diet, though its cultivation in Mediterranean countries is progressively declined, hence presently the extent of importation in the area is increasing (Rubiales, 2015). In spite of the regressive pattern of production, farmers, food industries, and consumers are increasingly demanding autochthonous common beans. Italian consumers often prefer their own landraces, being the major component of many traditional dishes and an integral part of their culture and traditions (Piergiovanni and Lioi, 2010; Montesano et al., 2012). Efforts to promote the on farm maintenance of the autochthonous landraces superior for seed composition and technological quality are in progress in Italy. Common bean seeds are not only an important source of vegetable proteins, starch, dietary fiber, and minerals, but also of bioactive and antinutritional compounds that can affect the metabolism in humans and animals (Sparvoli et al., 2015). For these reasons, there is an increasing attention toward the potential health benefits of this pulse (Campos-Vega et al., 2011; Blair, 2013; Sparvoli et al., 2016). Several studies link common beanconsumption to reduced risk of several diseases (Bazzano et al., 2001; Bourdon et al., 2001). Protease inhibitors (Kennedy 1998, 2006), phenolic compounds, anthocyanins, flavonoids, flavones, tannins (CardadorMartines et al., 2006; Golam Masum Akond et al., 2011; ChávezSantoscoy et al., 2013), saponins, and non-digestible fiber (Feregrino-Perez et al., 2014) are responsible of the health properties.

Phosphorus (P) is an essential element for plant growth, although grain legumes show different ability to use $\mathrm{P}$ contained in soil, and respond to fertilisers. In common bean, as well as in all legumes, a large proportion of phosphorus is present as phytic acid (Phy), myo-inositol hexakisphosphate (Lott et al., 2000). The complex of phytic acid and some microelements in the form of phytate is negatively associated with mineral bioavailability, leading to a reduction in assimilation of bivalent cations (Frossard et al., 2000; Petry et al., 2014; Bohn et al., 2008). At the same time, phytates have antioxidant properties, and have a role in the reduction of risk of cancer and other pathologies (Vucenik and Shamsuddin, 2006; Silva and Bracarense, 2016). One of the goals of bean breeders has been to reduce phytate accumulation increasing the proportion of inorganic phosphorus. Low Phy mutants have been obtained for most important crops and recently also for common bean (Campion et al., 2009). However, the reduction of phytates must take into account various issues related to their role 
in making common bean a functional food (Panzeri et al., 2011; Sparvoli et al., 2016). Therefore, if common bean has to become a competitive source of phytonutrients, to look for good genotypes combined with optimal growing conditions, are critical points. It is well known that seed traits (i.e.: protein and ash contents, cooking time, etc.) are affected by genetic and environmental factors, such as genotype, growing location, climatic conditions, and cultivation year (Kumar et al., 2006; Nikolopoulou et al., 2007; Piergiovanni et al., 2000).

The objective of the present study was to compare ten common bean landraces with regard to grain content of total and inorganic phosphorus, and phytates. The effect of growing location, in and out the traditional cultivation area was evaluated. Moreover, in order to acquire additional information about seed quality, protein and ash contents, coat percentage, and cooking time. were investigated.

\section{Materials and methods}

\section{Seed material}

The ten common bean landraces listed in Table 1, were gathered from a local farmer traditionally growing them at Sarconi (Basilicata region, Southern Italy). The six landraces, Ciuoto, Verdolino, Tabacchino, Munachedda, Tuvagliedda, and San Michele, obtained in 1996 the PGI mark of European Community (dossier number IT/PGI/0017/1531).

\section{Field trials}

The landraces were grown for three subsequent growing seasons (2012-2014) in the traditional area of cultivation at Sarconi (40.2486, 15.8865). This location, at about $638 \mathrm{~m}$ asl, is dominated by a Mediterranean climate, with mild winters, and dry and warm summers. The mean rainfall during the cultural cycle was $224 \mathrm{~mm}$, the mean temperatures were 12.6 and $27.0^{\circ} \mathrm{C}$ (minimum and maximum, respectively) over the three growing seasons. The soil is sand and loam-clay (51 and 49\%, respectively), neutral in reaction ( $\mathrm{pH} 7.1)$, with traces of limestone, a medium-high level of total nitrogen $(1.8 \%)$ and $1.8 \%$ of organic matter.

To evaluate the influence of growing location, field trials were performed for two years (2013 and 2014) also at Policoro (40.1907, 16.6446 Basilicata region, Italy). This location, placed at about $15 \mathrm{~m}$ asl, and characterised by a sub-humid climate, is outside the traditional area of cultivation of the landraces. The mean rainfall during the cultural cycle was $166 \mathrm{~mm}$, the mean temperatures were 17.4 and $31.0^{\circ} \mathrm{C}$ (minimum and maximum, respectively) over the two growing seasons. The soil is classified as alluvial silty-clay (40,37, and $23 \%$ of sand, silt, and clay, respectively), sub-alkaline in reaction ( $\mathrm{pH}$ 7.9). Furthermore, it is highly fertile, well equipped with nitrogen and rich in phosphorus (Negro et al., 2016).

Field trials were carried out according to the production protocol of common beans from Sarconi (http://ec.europa.eu/agriculture/quality/door/registeredName.html?denominationId=301)

Sowing was performed on the first and third decades of June at Policoro and Sarconi, respectively. A complete randomised block design was adopted with four repetitions. Seed density was 80-100 $\mathrm{kg} \mathrm{ha}{ }^{-1}$, and weed control was mechanically performed. Harvesting occurred on the first decade of October at Policoro and the third decade of September at Sarconi.

\section{Seed quality traits}

For each landrace, equal amounts of seeds randomly selected from the each of the four field repetitions were mixed to obtain the bulk used for the analyses. About $50 \mathrm{~g}$ of dry seeds were ground in a Cyclotec 1093 mill (Tecator, Hillerød, Denmark) to obtain a fine meal used for the following measurements. Moisture was determined by loss of weight after meal drying in an oven (AOAC method 930.15); protein contents were determined by microKjeldahl method ( $\mathrm{N} \times$ 6.25), following the AOAC method 979.09 (AOAC, 1970). Ash content was measured according to AOAC (method 923.03). Total $\mathrm{P}$ was determined by the colorimetric method of Fiske and Subbarow (1925). Inorganic phosphorus was measured on aliquots of acidic extracts according to Campion et al. (2009), whereas phytic acid was determined on aliquots of acidic extracts subjected to ferric precipitation as described by Pilu et al. (2003).

Coat percentage, calculated respect to the whole seed weight, was measured on 30 seeds randomly selected. After $24 \mathrm{~h}$ of seed soaking, coats were manually separated and oven dried overnight. Fifty seeds, soaked overnight at room temperature, were used to carry out the cooking test. After $20 \mathrm{~min}$ of cooking, the seed softness was measured every 2 min on three seeds until complete cooking.

\section{Statistical analysis}

Mean values of recorded traits were subjected to the Duncan's test. Associations among the traits were established by correlation analysis. The analysis of variance (one-way ANOVA) was performed to evaluate the role of season, genotype, and growing location. To perceive the differences among the harvests of the two locations, normalised data were submitted to the Principal Component Analysis (PCA). STATISTICA software package, version 7.1 (StatSoft, Tulsa, OK, USA) was used for all statistical analyses.

\section{Results and discussion}

\section{Phosphorus accumulation and partitioning in seeds}

The contents of total and inorganic phosphorus $\left(\mathrm{P}_{\text {tot }}\right.$ and $\mathrm{P}_{\mathrm{i}}$, respectively), and phytate (Phy) recorded at Sarconi, the traditional growing location of the landraces, are reported in Table 1. Overall, the mean values of total and partitioned phosphorus (Phy and $\mathrm{P}_{\mathrm{i}}$ ), were not significantly different among the three growing seasons. The values of $\mathrm{P}_{\text {tot }}$ cover a very broad range (2.62-5.17 $\left.\mathrm{g} \mathrm{kg}^{-1}\right)$. The extreme values were recorded in different years for Munachedda and Nasieddu nero in 2012 and 2013, respectively. A so wide variation is in agreement with previous studies available in the literature. For example, Blair et al. (2009), who analysed recombinant inbred lines, reported $\mathrm{P}_{\text {tot }}$ amounts ranging from to 2.8 to $6.8 \mathrm{~g} \mathrm{~kg}^{-1}$, while Beebe et al. (2000), screening 29 common bean varieties, found values comprised from 3.7 to $7.1 \mathrm{~g} \mathrm{~kg}^{-1}$.

The quantification of the fraction of phosphorus in the form of Phy provides an important information on how much P is committed to Phy. Although Phy content of seeds largely depends on environmental factors, previous studies demonstrated that a natural pronounced variability is present in both wild and cultivated common beans (Ariza-Nieto et al., 2007; Guzmán-Maldonado et al., 2000; Piergiovanni et al., 2000). The results of the Phy determinations carried out in the present investigation confirm the variation 
of this parameter within the cultivated common bean. The highest observed value was about twice the lowest one (5.68 vs $10.94 \mathrm{~g}$ $\mathrm{kg}^{-1}$ ), and both these extremes were recorded in 2014 (Table 1). Moreover, our variation partially overlaps to the range 9.8-22.6 g $\mathrm{kg}^{-1}$ reported by Guzmán-Maldonado et al. (2000).

The primary functions of Phy in seeds are phosphate storage as energy source and antioxidant for germinating seeds. Current literature suggests that Phy content in bean seeds explains from $53 \%$ to $81 \%$ of total $\mathrm{P}$, and that more than $95 \%$ of seed phytic acid is accumulated into the cotyledons (Lott et al., 2000; Ariza-Nieto et al., 2007). In good agreement with the literature, we found $\mathrm{Phy} / \mathrm{P}_{\text {tot }}$ ratios ranging from $44 \%$ to $75 \%$, with a mean value over the three years equal to $57.0 \% \pm 5.78$. The extreme values were recorded in different years and for diverse landraces $(44.0 \%$ for Tuvagliedda in 2014 and $75.5 \%$ for Munachedda in 2012), but no significant differences were observed among the Phy/ $/ \mathrm{P}_{\text {tot }}$ mean values (Table 1 ).

Inorganic $\mathrm{P}$ is another important kind of phosphorus accumulation. Although it is present into the grains at low concentrations, high levels are regarded as desirable from a nutritional point of view. Over the three growing seasons, an appreciable variation was observed also for $\mathrm{P}_{\mathrm{i}}$, being the recorded values comprised from 0.518 to $0.894 \mathrm{~g} \mathrm{~kg}^{-1}$ for Tuvagliedda rossa and Munachedda, in
2013 and 2014, respectively (Table 1).

The quality of common bean grains depends on many seed features at harvest time. For this reason, some of the most relevant parameters related to common bean economic value (i.e.: hundredseed weight, protein and ash contents, coat, cooking time) were determined (Table 2). Overall, the seed quality was good and the mean value of scored traits resulted not significantly affected by growing season, with the exception of 100 seed weight and coat content. The results of the correlation analysis are summarised in Table 3. According to Blair et al. (2012), the correlations of 100seed weight with $\mathrm{P}_{\text {tot }}$, Phy or $\mathrm{P}_{\mathrm{i}}$ resulted not statistically significant, whereasa significant correlation $(\mathrm{P}<0.05)$ between Phy and ash was found. This is attributable to the interdependence of ash amount from mineral elements accumulated in grains. Raboy et al. (1991) found a correlation between Phy and protein content. In the present study, the correlation between these traits resulted positive but not statistically significant (Table 3). Several studies point out that phytic acid metabolism in grains or leaves is sensitive to cellular level of $\mathrm{P}_{\mathrm{i}}$, which leads to increased translocation of $\mathrm{P}$ towards grain (Raboy and Dickinson, 1993). In this investigation, a positive correlation statistically significant $(\mathrm{P}<0.01)$ between $\mathrm{P}_{\text {tot }}$ and Phy was found (Table 3).

Table 1. Phosphorus partitioning in seed cultivated at Sarconi for three subsequent growing seasons.

\begin{tabular}{|c|c|c|c|c|c|c|c|c|c|c|c|c|c|}
\hline \multirow{2}{*}{$\begin{array}{l}\text { Work } \\
\text { code }\end{array}$} & \multirow[t]{2}{*}{ Landrace } & \multicolumn{3}{|c|}{$P_{\text {tot }}\left(\mathrm{g} \mathrm{kg}^{-1}\right)$} & \multicolumn{3}{|c|}{ Phytate $\left(\mathrm{g} \mathrm{kg}^{-1}\right)$} & \multicolumn{3}{|c|}{$P_{i}\left(g^{k g} g^{-1}\right)$} & \multicolumn{3}{|c|}{$\mathbf{P}_{\text {Phy }} / \mathbf{P}_{\text {tot }}(\%)$} \\
\hline & & 2012 & 2013 & 2014 & 2012 & 2013 & 2014 & 2012 & 2013 & 2014 & 2012 & 2013 & 2014 \\
\hline 1 & Riso & 3.87 & 4.21 & 3.58 & 7.98 & 8.64 & 6.54 & 0.677 & 0.758 & 0.792 & 58.1 & 57.8 & 51.4 \\
\hline 2 & Ciuoto & 3.61 & 3.96 & 4.61 & 7.34 & 7.51 & 9.18 & 0.536 & 0.741 & 0.710 & 57.3 & 53.3 & 56.2 \\
\hline 3 & Verdolino & 4.80 & 4.72 & 4.44 & 9.10 & 9.19 & 10.42 & 0.689 & 0.785 & 0.711 & 53.3 & 54.9 & 66.2 \\
\hline 4 & Tabacchino & 3.40 & 4.65 & 5.23 & 8.02 & 9.84 & 10.94 & 0.789 & 0.849 & 0.772 & 66.5 & 59.5 & 58.9 \\
\hline 5 & Munachedda & 2.62 & 4.25 & 4.16 & 7.03 & 8.39 & 8.21 & 0.676 & 0.588 & 0.894 & 75.5 & 55.5 & 55.5 \\
\hline 6 & Munachedda nera & 4.62 & 4.20 & 3.89 & 7.78 & 8.28 & 7.18 & 0.671 & 0.658 & 0.716 & 47.4 & 55.4 & 51.9 \\
\hline 7 & Tuvagliedda & 4.36 & 4.50 & 3.64 & 9.45 & 9.32 & 5.68 & 0.668 & 0.666 & 0.641 & 61.0 & 58.2 & 44.0 \\
\hline 8 & Tuvagliedda rossa & 3.60 & 3.95 & 3.58 & 7.93 & 7.79 & 6.76 & 0.754 & 0.518 & 0.544 & 62.0 & 55.7 & 53.1 \\
\hline 9 & San Michele & 3.88 & 4.16 & 4.00 & 7.68 & 8.41 & 8.39 & 0.557 & 0.667 & 0.826 & 55.7 & 57.0 & 59.0 \\
\hline 10 & Nasieddu nero & 4.16 & 5.17 & 3.47 & 8.85 & 10.46 & 6.63 & 0.641 & 0.598 & 0.624 & 59.8 & 56.9 & 53.9 \\
\hline Mean & & $3.89^{\mathrm{a}}$ & $4.38^{\mathrm{a}}$ & $4.06^{\mathrm{a}}$ & $8.12^{\mathrm{a}}$ & $8.78^{a}$ & $7.99^{\mathrm{a}}$ & $0.666^{\mathrm{a}}$ & $0.683^{\mathrm{a}}$ & $0.723^{\mathrm{a}}$ & $59.7^{\mathrm{a}}$ & $56.4^{\mathrm{a}}$ & $55.0^{\mathrm{a}}$ \\
\hline SD & & 0.639 & 0.382 & 0.562 & 0.777 & 0.916 & 1.754 & 0.077 & 0.101 & 0.103 & 7.597 & 1.813 & 5.838 \\
\hline
\end{tabular}

P, phosphorus; SD, standard deviation. Values expressed on dry matter basis. avalues followed by the same letter are not significantly different $(\mathrm{P}>0.05)$.

Table 2. Quality traits of seed cultivated at Sarconi for three subsequent growing seasons.

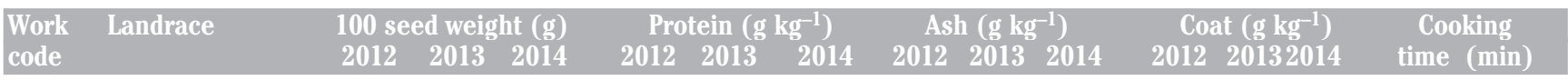

\begin{tabular}{|c|c|c|c|c|c|c|c|c|c|c|c|c|c|c|c|c|}
\hline 1 & Riso & 49.2 & 58.6 & 47.9 & 218.5 & 222.8 & 217.7 & 39.6 & 39.7 & 37.3 & 56.4 & 47.1 & 51.5 & 42 & 34 & 36 \\
\hline 2 & Ciuoto & 38.0 & 43.4 & 37.7 & 186.6 & 186.5 & 193.4 & 37.4 & 39.3 & 45.0 & 67.0 & 59.0 & 58.1 & 32 & 34 & 33 \\
\hline 3 & Verdolino & 37.5 & 50.4 & 39.4 & 216.0 & 225.4 & 208.4 & 39.5 & 40.2 & 40.7 & 61.6 & 50.6 & 53.5 & 34 & 36 & 32 \\
\hline 4 & Tabacchino & 37.9 & 43.8 & 42.9 & 223.5 & 265.3 & 267.3 & 39.1 & 39.4 & 39.5 & 62.0 & 57.4 & 57.4 & 40 & 30 & 36 \\
\hline 5 & Munachedda & 48.5 & 59.4 & 62.8 & 222.2 & 213.5 & 250.8 & 39.2 & 42.7 & 40.0 & 67.1 & 54.7 & 56.0 & 34 & 34 & 42 \\
\hline 6 & Munachedda nera & 46.4 & 60.4 & 51.1 & 264.2 & 255.0 & 238.6 & 41.8 & 41.1 & 43.3 & 69.6 & 60.1 & 61.7 & 40 & 38 & 40 \\
\hline 7 & Tuvagliedda & 58.2 & 68.3 & 69.0 & 246.2 & 248.9 & 219.7 & 47.3 & 41.1 & 38.3 & 55.3 & 47.8 & 54.4 & 44 & 38 & 41 \\
\hline 8 & Tuvagliedda rossa & 52.2 & 59.0 & 59.9 & 241.2 & 237.2 & 245.1 & 39.7 & 42.5 & 38.3 & 77.1 & 59.3 & 61.3 & 53 & 38 & 46 \\
\hline 9 & San Michele & 34.3 & 60.5 & 38.7 & 224.6 & 229.8 & 253.4 & 45.8 & 40.1 & 45.6 & 72.7 & 54.5 & 68.8 & 34 & 38 & 36 \\
\hline 10 & Nasieddu nero & 53.2 & 52.9 & 61.6 & 240.6 & 235.5 & 239.0 & 41.9 & 48.6 & 38.9 & 75.0 & 61.5 & 64.0 & 44 & 34 & 39 \\
\hline Mean & & $45.5^{\mathrm{a}}$ & $55.7^{\mathrm{bc}}$ & $51.1^{\mathrm{ac}}$ & $228.4^{\mathrm{a}}$ & $232.0^{\mathrm{a}}$ & $233.3 \mathrm{a}$ & $41.1^{\mathrm{a}}$ & $41.5^{\mathrm{a}}$ & $40.7^{\mathrm{a}}$ & $66.4^{\mathrm{a}}$ & $55.2^{\mathrm{bc}}$ & $58.7^{\mathrm{bc}}$ & $39.7^{\mathrm{a}}$ & $35.4^{\mathrm{a}}$ & $38.1^{\mathrm{a}}$ \\
\hline SD & & 8.113 & 7.928 & 11.511 & 21.048 & 22.381 & 22.868 & 3157 & 2.775 & 2.935 & 7.490 & 5.186 & 5.297 & 6.464 & 2.675 & 4.306 \\
\hline
\end{tabular}

SD, standard deviation. Values expressed on dry matter basis. ${ }^{\mathrm{a}-\mathrm{c}}$ Values followed by the same letter are not significantly different $(\mathrm{P}>0.05)$. 


\section{Comparative evaluation of landraces}

Common bean genotypes vary in their efficiency of P uptake from soil, capability to store and partitioning it among different forms (Coelho et al., 2002). Experimental data collected in the present study are in good agreement with literature. Analysing in

Table 3. Correlation coefficients among the traits recorded at Sarconi in the growing seasons 2012-2014.

\begin{tabular}{lccccccc} 
& Phy & $P_{i}$ & $\begin{array}{c}\text { Ash } 100 \text { seed Protein } \\
\text { weight }\end{array}$ & $\begin{array}{c}\text { Coat Cooking } \\
\text { time }\end{array}$ \\
$\mathrm{P}_{\text {tot }}$ & $0.81^{* *}$ & 0.16 & 0.40 & -0.09 & -0.30 & 0.27 & -0.28 \\
Phy & - & 0.25 & $0.41^{*}$ & -0.24 & -0.22 & 0.24 & -0.30 \\
\hline$P_{i}$ & - & -0.18 & -0.19 & -0.23 & 0.23 & -0.03 \\
Ash & & - & -0.09 & 0.17 & 0.17 & -0.07 \\
\hline 100 seeds weight & & & - & $-0.37^{*}$ & 0.32 & $0.44^{*}$ \\
Coat & & & & - & 0.13 & 0.32 \\
\hline Protein & & & & & - & $0.36^{*}$ \\
\hline
\end{tabular}

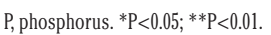

detail the data recorded for the three sequential harvests, differences among the landraces in the extent of year-to-year variation of the $\mathrm{P}$ forms investigated can be observed (Table 1). For example, Tabacchino, Munachedda and Nasieddu nero showed the higher year-to-year variation of $\mathrm{P}_{\text {tot }}$ content. Conversely, Tuvagliedda rossa and $\mathrm{S}$. Michele, showing very close $\mathrm{P}_{\text {tot }}$ amounts in the three years, appear scarcely affected by growing season.

Tabacchino, Tuvagliedda and Nasieddu nero showed the higher year-to-year variations of Phy level. For these landraces, the highest value was from 36 to $66 \%$ greater than the lowest one. As expected, the highest Phy amounts were recorded in 2013 or 2014 being it significantly correlated to $\mathrm{P}_{\text {tot }}$ (Table 1). Although the metabolism of $\mathrm{P}$ in common bean grains cannot entirely explained by differences in phytate content, these results suggest that the surplus of $\mathrm{P}$ accumulated was mainly stored in form of phytate. It is interesting to underline that $\mathrm{S}$. Michele presented the lowest variation of both $\mathrm{P}_{\text {tot }}$ and Phy levels among the three harvests (Table 1). This suggests that the capacity of $\mathrm{P}$ accumulation and partitioning of this genotype is scarcely influenced by the year of cultivation. Finally, Munachedda, Tuvagliedda rossa and S. Michele showed very broad ranges of variation for $\mathrm{P}_{\mathrm{i}}$ over the three growing seasons. This suggests that for these landraces the different quantities of $\mathrm{P}$ accumulated were mainly converted in $\mathrm{P}_{\mathrm{i}}$.

Table 4. Seed traits of landraces cultivated at Policoro for two subsequent growing seasons. Upper section: phosphorus accumulation and partitioning; lower section: seed quality traits.

\begin{tabular}{|c|c|c|c|c|c|c|c|c|c|c|c|}
\hline \multirow{2}{*}{$\begin{array}{l}\text { Work } \\
\text { code }\end{array}$} & \multirow[t]{2}{*}{ Landrace } & \multicolumn{2}{|c|}{$\mathbf{P}_{\text {tot }}\left(\mathrm{g} \mathrm{kg}^{-1}\right)$} & \multicolumn{3}{|c|}{ Phytate $\left(\mathrm{g} \mathrm{kg}^{-1}\right)$} & \multicolumn{2}{|c|}{ Pi $\left(\mathrm{g} \mathrm{kg}^{-1}\right)$} & \multicolumn{3}{|c|}{$\mathrm{PP}_{\mathrm{hy}} / \mathbf{P}_{\text {tot }}(\%)$} \\
\hline & & 2013 & 2014 & \multicolumn{2}{|c|}{2013} & 2014 & 2013 & & \multicolumn{2}{|c|}{2013} & 2014 \\
\hline 1 & Riso & 5.40 & 5.20 & \multicolumn{2}{|c|}{12.51} & 10.97 & 0.755 & & \multicolumn{2}{|c|}{65.2} & 59.4 \\
\hline 2 & Ciuoto & 4.93 & 5.15 & \multicolumn{2}{|c|}{10.43} & 11.00 & 1.116 & 0.575 & \multicolumn{2}{|c|}{59.6} & 60.1 \\
\hline 3 & Verdolino & 5.20 & 5.80 & \multicolumn{2}{|c|}{11.38} & 12.10 & 0.675 & 0.653 & \multicolumn{2}{|c|}{61.6} & 58.8 \\
\hline 4 & Tabacchino & 4.64 & 5.42 & \multicolumn{2}{|c|}{9.42} & 11.92 & 0.571 & \multicolumn{2}{|c|}{0.583} & 57.1 & 66.0 \\
\hline 5 & Munachedda & 4.72 & 5.06 & \multicolumn{2}{|c|}{10.20} & 10.84 & 0.658 & \multicolumn{2}{|c|}{0.668} & 60.7 & 60.2 \\
\hline 6 & Munachedda nera & 5.58 & 5.07 & \multicolumn{2}{|c|}{11.74} & 10.50 & 0.731 & & & 9.3 & 58.4 \\
\hline 7 & Tuvagliedda & 4.92 & 4.66 & 9.8 & & 9.04 & 0.600 & & & 6.5 & 54.7 \\
\hline 8 & Tuvagliedda rossa & 4.91 & 4.95 & 9.4 & & 11.32 & 0.535 & & & 3.9 & 64.5 \\
\hline 9 & San Michele & 5.45 & 5.45 & 10. & & 11.23 & 0.669 & & & 5.6 & 57.9 \\
\hline 10 & Nasieddu nero & 5.40 & 4.28 & 10. & & 9.98 & 0.621 & & & 5.2 & 65.6 \\
\hline Mean & & $5.12^{\mathrm{a}}$ & $5.10^{\mathrm{a}}$ & 10. & & $10.89^{\mathrm{a}}$ & $0.693^{\mathrm{a}}$ & & & $8.7^{\mathrm{a}}$ & $60.6^{\mathrm{a}}$ \\
\hline SD & & 0.332 & 0.424 & 1.0 & & 0.897 & 0.163 & & & 458 & 3.672 \\
\hline & & $\begin{array}{c}100 \text { seec } \\
2013\end{array}$ & $\begin{array}{l}\text { weight (g) } \\
2014\end{array}$ & $\begin{array}{l}\text { Prot } \\
2013\end{array}$ & $\begin{array}{l}\left(\mathrm{g} \mathrm{kg}^{-1}\right) \\
2014\end{array}$ & $\begin{array}{r}\text { Ash } \\
2013\end{array}$ & $\begin{array}{l}\left.\mathrm{kg}^{-1}\right) \\
2014\end{array}$ & $\begin{array}{l}\text { Co: } \\
2013\end{array}$ & $\begin{array}{l}\left.g^{-1}\right) \\
2014\end{array}$ & $\begin{array}{c}\text { Cookin } \\
2013\end{array}$ & $\begin{array}{l}\text { (min) } \\
2014\end{array}$ \\
\hline 1 & Riso & 43.0 & 38.9 & 298.1 & 244.2 & 44.0 & 47.8 & 53.5 & 59.6 & 32 & 35 \\
\hline 2 & Ciuoto & 38.9 & 31.9 & 265.9 & 211.9 & 45.0 & 45.0 & 58.4 & 66.1 & 32 & 33 \\
\hline 3 & Verdolino & 32.1 & 32.7 & 241.5 & 241.6 & 44.5 & 46.0 & 57.0 & 62.6 & 32 & 34 \\
\hline 4 & Tabacchino & 36.1 & 34.5 & 235.9 & 240.0 & 45.2 & 47.9 & 60.7 & 61.9 & 34 & 38 \\
\hline 5 & Munachedda & 38.3 & 34.4 & 232.3 & 235.3 & 49.6 & 51.6 & 61.1 & 67.9 & 30 & 36 \\
\hline 6 & Munachedda nera & 38.5 & 39.5 & 257.9 & 251.8 & 52.6 & 47.7 & 72.0 & 65.9 & 32 & 32 \\
\hline 7 & Tuvagliedda & 47.9 & 45.7 & 242.3 & 232.8 & 46.7 & 47.4 & 54.7 & 53.8 & 32 & 35 \\
\hline 8 & Tuvagliedda rossa & 50.1 & 42.1 & 222.6 & 246.8 & 47.6 & 45.4 & 63.0 & 64.0 & 36 & 36 \\
\hline 9 & San Michele & 31.8 & 43.9 & 242.0 & 251.4 & 48.9 & 47.1 & 70.4 & 68.6 & 34 & 37 \\
\hline 10 & Nasieddu nero & 51.2 & 36.5 & 227.9 & 235.9 & 46.5 & 47.9 & 69.7 & 67.8 & 34 & 34 \\
\hline Mean & & $40.8^{a}$ & $38.0^{\mathrm{a}}$ & $246.6^{\mathrm{a}}$ & $239.2^{\mathrm{a}}$ & $47.1^{\mathrm{a}}$ & $47.4^{\mathrm{a}}$ & $62.0^{\mathrm{a}}$ & $63.8^{\mathrm{a}}$ & $32.8^{\mathrm{a}}$ & $35.0^{\mathrm{b}}$ \\
\hline SD & & 7.022 & 4.793 & 22.268 & 11.591 & 2.685 & 1.832 & 6.641 & 4.570 & 1.687 & 1.826 \\
\hline
\end{tabular}

P, phosphorus; SD, standard deviation. Values expressed on dry matter bases. ${ }^{\mathrm{a}, \mathrm{b}}$ Values followed by the same letter are not significantly different $(\mathrm{P}>0.05)$. 
As concerns nutritional traits (Table 2), the lowest protein content was recorded for Ciuoto confirming previous studies (Piergiovanni et al., 2000). At the opposite, higher values were associated to Tabacchino and Munachedda. The cooking times showed an appreciable variation both among landraces as well as among growing seasons. Conversely, very a low variation was associated to ash amount.

Several studies showed the existence of correlations between climatic conditions (i.e. monthly average temperature, rainfall quantity) during the plant development and levels of antinutritionals in seeds (Kumar et al., 2006; Nikolopoulou et al., 2007; Piergiovanni et al., 2011). To shed light on the role of growing location climate on $\mathrm{P}$ accumulation and partitioning in common bean, monthly average temperature and rainfall quantity recorded at Sarconi in the years 2012-2014 from June to October, were examined. On monthly base, the maximum average temperatures recorded in 2012 during the complete crop cycle, were superior to those recorded in 2013 and 2014. The 2013 was the rainiest year with $316 \mathrm{~mm}$ of rain against 165 and $190 \mathrm{~mm}$ in 2012 and 2014, respectively. When these meteorological data are matched with $\mathrm{P}$ data, rainfall quantity seems to promote the accumulation in seeds of both $\mathrm{P}_{\text {tot }}$ and Phy (Table 1). Riso, Munachedda, Munachedda nera and Nasieddu nero appear to be the more sensitive to rainfall showing the highest $P_{\text {tot }}$ and Phy values in 2013.

\section{Influence of growing location}

Due to the differences in $\mathrm{P}$ accumulation and partitioning recorded at Sarconi among the landraces in 2012, it was planned to grow them in another location. It is known that, the comparison of a group of genotypes grown for subsequent seasons in different locations, where the level of plant stress is different, can provide interesting information about the environmental effects on grain composition. To amplify the genotype $\mathrm{x}$ environment interaction, the trial was carried out at Policoro, a location of Basilicata region, outside the traditional area of cultivation of these landraces. Data collected at Policoro, summarised in Table 4, show similarities with those of Sarconi (Table 1) in $\mathrm{P}$ accumulation and partitioning. For example, Nasieddu nero showed a high $\mathrm{P}_{\text {tot }}$ variation between 2013 and 2014 at both locations, and the lowest values were recorded in 2014. Ciuoto, Verdolino and Tabacchino showed higher values of Phy at both locations in 2014. Finally, the lack of appreciable variation of Phy content for Munachedda and S. Michele was observed also at Policoro. It is interesting to underline that $\mathrm{P}$ accumulation and partitioning detected in $\mathrm{S}$. Michele were scarcely affected by growing season at both locations (Tables 1 and 4). The comparison of data relative at the two locations is showed in Table 5. The $\mathrm{P}_{\text {tot }}$ and Phy mean values were significantly different $(\mathrm{P}<0.05)$ between the locations in 2013 and 2014. The higher values were always detected at Policoro. Conversely, $\mathrm{P}_{\mathrm{i}}$ mean values were significantly different between the locations only in 2014 , but the highest value was observed at Sarconi. As concern nutritional traits, ash and coat mean values were also significantly different between Sarconi and Policoro in both years.

Results of ANOVA analysis applied to experimental data collected in this study are resumed in Table 6 . The effects of growing season and genotype resulted not significant in determining $\mathrm{P}$ accumulation and partitioning, whereas were significant on the other analysed traits (seed size, protein content, cooking time). Conversely, the growing location significantly affected all traits with the exception of 100 seed weight and protein content (Table 6). This is mainly attributable to differences in soil composition and environmental conditions between the locations. Actually, Sarconi's soil is not calcareous (less than $0.5 \%$ ) and has a neutral
$\mathrm{pH}$, while at Policoro the carbonate in soil is about $25 \%$, and the $\mathrm{pH}$ is alkaline. When data relative to Sarconi and Policoro harvests for both years, were submitted to principal component analysis (PCA) the scatter plot in Figure 1 was obtained. The first three components accounted for the $79.1 \%$ of observed variance. The first component (PCA1) has high negative loadings on $\mathrm{P}_{\mathrm{i}}$ and 100 seed weight; the second one (PCA2) has high negative loadings on $\mathrm{P}_{\mathrm{i}}$ and Phy. The effect of growing location is clear-cut being the landraces divided in two distinguishable subgroups associated to Sarconi and Policoro (S and P, respectively). Tabacchino appeared the less influenced by growing location, being the points representing the harvests at the two locations (4P and $4 \mathrm{~S}$ ) very close in the scatter plot.

Table 5. Comparison of mean values of seed traits recorded at Sarconi and Policoro locations.

\begin{tabular}{lcccc} 
& \multicolumn{2}{c}{2013} & \multicolumn{2}{c}{2014} \\
& Sarconi & Policoro & Sarconi & Policoro \\
$\mathrm{P}_{\text {tot }}\left(\mathrm{g} \mathrm{kg}^{-1}\right)$ & $4.38^{\mathrm{a}}$ & $5.12^{\mathrm{b}}$ & $4.06^{\mathrm{a}}$ & $5.10^{\mathrm{b}}$ \\
$\mathrm{Phy}\left(\mathrm{g} \mathrm{kg}^{-1}\right)$ & $8.78^{\mathrm{a}}$ & $10.63^{\mathrm{b}}$ & $7.9^{\mathrm{a}}$ & $10.89^{\mathrm{b}}$ \\
\hline $\mathrm{P}_{\mathrm{i}}\left(\mathrm{g} \mathrm{kg}^{-1}\right)$ & $0.683^{\mathrm{a}}$ & $0.693^{\mathrm{a}}$ & $0.723^{\mathrm{b}}$ & $0.584^{\mathrm{a}}$ \\
$100 \mathrm{seed}$ weight & $55.7^{\mathrm{a}}$ & $40.8^{\mathrm{b}}$ & $51.1^{\mathrm{a}}$ & $38.0^{\mathrm{b}}$ \\
\hline Protein & $232.0^{\mathrm{a}}$ & $246.6^{\mathrm{a}}$ & $233.3^{\mathrm{a}}$ & $239.2^{\mathrm{a}}$ \\
Ash & $41.5^{\mathrm{a}}$ & $47.1^{\mathrm{b}}$ & $40.7^{\mathrm{a}}$ & $47.4^{\mathrm{b}}$ \\
\hline Coat & $55.2^{\mathrm{a}}$ & $62.0^{\mathrm{b}}$ & $58.7^{\mathrm{a}}$ & $63.8^{\mathrm{b}}$ \\
Cooking time & $35.4^{\mathrm{a}}$ & $32.8^{\mathrm{b}}$ & $38.1^{\mathrm{a}}$ & $35.0^{\mathrm{a}}$ \\
\hline
\end{tabular}

a,bValues followed by the same letter are not significantly different $(\mathrm{P}>0.05)$.

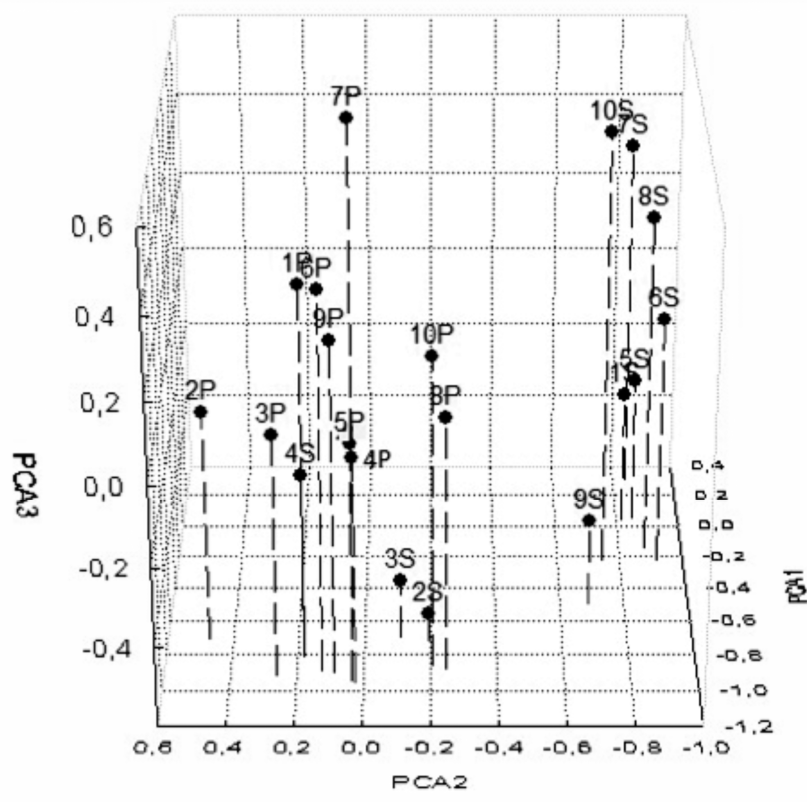

Figure 1. Three-dimensional scatter plot of the principal component analysis (PCA) based on data of the harvest of the two growing locations: Sarconi (S), Policoro (P). The landrace codes are as in Table 1. 
Table 6. Analysis of variance over harvests at Sarconi and Policoro locations.

\begin{tabular}{|c|c|c|c|c|c|c|c|c|c|c|c|}
\hline Source of variation & & DF & $P_{\text {tot }}$ & Phy & $P_{i}$ & $\mathbf{P}_{\text {Phy }} / \mathbf{P}_{\text {tot }}$ & Ash & 100 seed weight & Coat & Protein & Cooking time \\
\hline $\begin{array}{l}\text { Sarconi: growing } \\
\text { seasons 2012-2014 }\end{array}$ & $\begin{array}{l}\text { Year } \\
\text { Landrace }\end{array}$ & $\begin{array}{l}2 \\
9\end{array}$ & $\begin{array}{l}0.607 \\
0.283\end{array}$ & $\begin{array}{l}1.807 \\
1.674\end{array}$ & $\begin{array}{l}0.009 \\
0.011\end{array}$ & $\begin{array}{l}56.847 \\
29.759\end{array}$ & $\begin{array}{l}1.529 \\
8.080\end{array}$ & $\begin{array}{c}257.359 \\
210.603^{* *}\end{array}$ & $\begin{array}{c}3.275^{* *} \\
0.921\end{array}$ & $\begin{array}{c}66.333 \\
1087.243^{* *}\end{array}$ & $\begin{array}{c}47.233 \\
41.393^{*}\end{array}$ \\
\hline $\begin{array}{l}\text { Policoro: growing } \\
\text { seasons 2013-2014 }\end{array}$ & $\begin{array}{l}\text { Year } \\
\text { Landrace }\end{array}$ & $\begin{array}{l}1 \\
9\end{array}$ & $\begin{array}{l}0.000 \\
0.137\end{array}$ & $\begin{array}{l}0.341 \\
0.949\end{array}$ & $\begin{array}{l}0.059 \\
0.015\end{array}$ & $\begin{array}{c}21.840 \\
8.367\end{array}$ & $\begin{array}{l}0.512 \\
7.148\end{array}$ & $\begin{array}{l}38.642 \\
47.896\end{array}$ & $\begin{array}{c}0.157 \\
0.544^{*}\end{array}$ & $\begin{array}{l}279.004 \\
288.289\end{array}$ & $\begin{array}{c}24.200^{*} \\
4.200\end{array}$ \\
\hline $\begin{array}{l}\text { Sarconi and Policoro: } \\
\text { growing seasons 2013-2014 }\end{array}$ & $\begin{array}{l}\text { Year } \\
\text { Landrace } \\
\text { Location }\end{array}$ & $\begin{array}{l}1 \\
9 \\
1 \\
\end{array}$ & $\begin{array}{c}0.269 \\
0.193 \\
7.939 * * \\
\end{array}$ & $\begin{array}{c}0.700 \\
1.878 \\
66.240^{* *}\end{array}$ & $\begin{array}{l}0.012 \\
0.020 \\
0.041 \\
\end{array}$ & $\begin{array}{c}1.156 \\
16.452 \\
144.400^{* *}\end{array}$ & $\begin{array}{c}0.529 \\
8.466 \\
376.996^{* *} \\
\end{array}$ & $\begin{array}{c}135.056 \\
169.431 \\
1955.802 \\
\end{array}$ & $\begin{array}{c}0.686 \\
0.946^{* *} \\
3.600^{* *} \\
\end{array}$ & $\begin{array}{c}93.636 \\
504.320 \\
1048.576 \\
\end{array}$ & $\begin{array}{c}60.025^{*} \\
11.725 \\
81.225^{* *} \\
\end{array}$ \\
\hline
\end{tabular}

P, phosphorus; DF, degrees of freedom. Mean squares and significance are reported. ${ }^{*} \mathrm{P}<0.05 ;{ }^{*} \mathrm{P}<0.01$

\section{Conclusions}

Many studies showed that some seed traits depend on genotype as well as environmental factors, such as soil and climate, during plant and seed development. Graham et al. (1999), analysing the micronutrient contents of some staple crops, observed that environmental effect appeared to be greater than genetic component. Kumar et al. (2006) who carried out a multi-location field trial, reported that phytic acid accumulation in soybean seeds is significantly affected by environment and genotype. The complexity of $\mathrm{P}$ metabolic pathway in plants depends on the interaction of several factors. So, present data related to aptitude to accumulate and partition phosphorus in seeds are preliminary indications about the differences among the studied landraces. The knowledge of performance of a common bean landrace in relation to cultivation area is important for its success and acceptance by farmers and consumers. The results collected in this study evidenced that cultivation outside the traditional environment appreciably affects the seed quality. These results confirm how the close link between landrace and a well-defined cultivation area, crucial for the attribution of European PGI mark, has a great importance not only to recognise the heritage of a local community, but also to safeguard the characteristics of the final product.

\section{References}

AOAC, 1970. Official methods of analysis. $11^{\text {th }}$ ed. Association of Official Agricultural Chemists, Washington, DC, USA.

Ariza-Nieto M, Blair M, Welch R, Glahn R, 2007. Screening of iron bioavailability patterns in eight bean (Phaseolus vulgaris L.) genotypes using the Caco-2 cell in vitro model. J. Agric. Food Chem. 55:7950-6.

Bazzano L, He J, Ogden LG, Loria C, Vupputuri S, Myers L, Whelton PK, 2001. Legume consumption and risk of coronary heart disease in US men and woman. Arch. Int. Med. 161:2573-8.

Beebe S, Gonzalez AV, Rengifo J, 2000. Research on trace minerals in the common bean. Food Nutr. Bull. 21:387-91.

Blair MW, 2013. Mineral biofortification strategies for food staples: the example of common bean. J. Agric. Food Chem. 61:8287-94.

Blair MW, Herrera AL, Sandoval TA, Caldas GV, Fileppi M, Sparvoli F, 2012. Inheritance of seed phytate and phosphorus levels in common bean (Phaseolus vulgaris L.) and association with newly-mapped candidate genes. Mol. Breed. 30:1265-77.

Blair MW, Sandoval TA, Caldas GV, Beebe SE, Páez MI, 2009. Quantitative trait locus analysis of seed phosphorus and seed phytate content in a recombinant inbred line population of common bean. Crop Sci. 49:237-46.

Bohn L, Meyer AS, Rasmussen SK, 2008. Phytate: impact on environment and human nutrition. A challenge for molecular breeding. J. Zhejiang Univ. Sci. B 9:165-91.

Bourdon I, Olson B, Backus R, Richter BD, Davis PA, Schneeman BO, 2001. Beans as a source of dietary fiber increase cholecystokinin and apolipoprotein b48 response to test meals in men. J. Nutr. 131:1485-90.

Campion B, Sparvoli F, Doria E, Tagliabue G, Galasso I, Fileppi M, Bollini R, Nielsen E, 2009. Isolation and characterisation of an lpa (low phytic acid) mutant in common bean (Phaseolus vulgaris L.). Theor. Appl. Genet. 118:1211-21.

Campos-Vega R, Vergara-Castañeda HA, Oomah BD, 2011. Functional food sources: beans in sight. In: E. Popoescu, I. Golubev (eds) Beans: nutrition consumption and health. Nova Science Publishers, New York, NY, USA, pp 1-56.

Cardador-Martines A, Albores A, Bah M, Calderon-Salinas V, Castañano-Tostado E, Guevara-Gonzalez R, ShimadaMiyasaka A, Loarca-Piña G, 2006. Relationship among antimutagenic antioxidant and enzymatic activities of methanolic extract from common beans (Phaseolus vulgaris L.). Plant Foods Hum. Nutr. 61:161-8.

Chávez-Santoscoy RA, Gutiérrez-Uribe JA, Serna-Saldívar SO, 2013. Effect of flavonoids and saponins extracted from black bean (Phaseolus vulgaris L.) seed coats as cholesterol micelle disruptors. Plant Foods Hum. Nutr. 68:416-23.

Coelho CMM, Pires Santos Jc, Tsai SM, Vitorello VA, 2002. Seed phytate content and phosphorous uptake and distribution in dry bean genotypes. Braz. J. Plant Physiol. 14:51-8.

Feregrino-Perez AA, Piñol-Felis C, Gomez-Arbones X, GuevaraGonzález RG, Campos-Vega R, Acosta-Gallegos J, LoarcaPiña G, 2014. A non-digestible fraction of the common bean (Phaseolus vulgaris L.) induces cell cycle arrest and apoptosis during early carcinogenesis. Plant Foods Hum. Nutr. 69:24854.

Fiske CH, Subbarow Y, 1925. The colorimetric determination of phosphorus. J. Biol. Chem. 66:375-9.

FAO, 2016. Food and Agriculture Organization, Statistic Division FAOSTAT, Rome, Italy. Available from: http://faostat3.fao. org/browse/Q/QC/E

Frossard E, Bucher M, Machler F, Mozafar A, Hurrell R, 2000. Potential for increasing the content and bioavailability of $\mathrm{Fe}$ $\mathrm{Zn}$ and $\mathrm{Ca}$ in plants for human nutrition. J. Sci. Food Agric. 80:861-79.

Golam Masum Akond ASM, Khandaker L, Berthold J, Gates L, Peters K, Delong H, Hossain K, 2011. Anthocyanin total polyphenols and antioxidant activity of common bean. Am. J. Food Technol. 6:385-94. 
Graham R, Senadhira D, Beebe S, Iglesias C, Monasterio I, 1999. Breeding for micronutrient density in edible portions of staple food crops: conventional approaches. Field Crops Res. 60:5780.

Guzmán-Maldonado SH, Acosta-Gallegos J, Paredes-López O, 2000. Protein and mineral content of a novel collection of wild and weedy common bean (Phaseolus vulgaris L.). J. Sci. Food Agric. 80:1874-81.

Kennedy AR, 1998. Chemopreventive agents: protease inhibitors Pharmacol. Ther. 78:167-209.

Kennedy AR, 2006. The status of human trials utilizing BowmanBirk inhibitor concentrate from soybean. In: M. Sugano (ed.) Soy in health and disease prevention. CRC Press, Boca Raton FL, USA, pp. 207-23.

Kumar V, Rani A, Solanki S, Hussain SM, 2006. Influence of growing environment on the biochemical composition and physical characteristics of soybean seed. J. Food Comp. Anal. 19:188-95.

Lott JNA, Ockenden I, Raboy V, Batten GD, 2000. Phytic acid and phosphorus in crop seeds and fruits: a global estimate. Seed Sci. Res. 10:11-33.

Montesano V, Negro D, Sarli G, Logozzo G, Spagnoletti Zeuli P, 2012. Landraces in inland areas of the Basilicata Region Italy: monitoring and perspectives for on farm conservation. Genet. Res. Crop Evol. 59:701-16.

Negro D, Montesano V, Sonnante G, Rubino P, De Lisi A, Sarli G, 2016. Fertilization strategies on cultivars of globe artichoke: effects on yield and quality performance. J. Plant Nutr. 39:27987.

Nikolopoulou D, Grigorakis K, Stasini M, Alexis MN, Iliadis K, 2007. Differences in chemical composition of field pea (Pisum sativum) cultivars: effects of cultivation area and year. Food Chem. 103:847-52

Panzeri D, Cassani E, Doria E, Tagliabue G, Forti L, Campion B, Bollini R, Brearley CA, Pilu R, Nielsen E, Sparvoli F, 2011. A defective ABC transporter of the MRP family responsible for the bean lpa1 mutation affects the regulation of the phytic acid pathway reduces seed myo-inositol and alters ABA sensitivity. New Phytol. 191:70-83.

Petry N, Egli I, Gahutu JB, Tugirimana PL, Boy E, Hurrell R,
2014. Phytic acid concentration influences iron bioavailability from biofortified beans in Rwandese women with low iron status. J. Nutr. 144:1681-7.

Piergiovanni AR, Cerbino D, Della Gatta C, 2000. Diversity in seed quality traits of common bean (Phaseolus vulgaris $\mathrm{L}$ ) populations from Basilicata (Southern Italy). Plant Breed. 119:513-6.

Piergiovanni AR, Lioi L, 2010. Italian common bean landraces: history, genetic diversity and seed quality. Diversity 2:837-62.

Piergiovanni AR, Lupo F, Zaccardelli M, 2011. Environmental effect on yield composition and technological seed traits of some Italian ecotypes of grass pea (Lathyrus sativus L). J. Sci. Food Agric. 91:122-9.

Pilu R, Panzeri D, Gavazzi G, Rasmussen SK, Consonni G, Nielsen E, 2003. Phenotypic genetic and molecular characterisation of a maize low phytic acid mutant (lpa 241). Theor. Appl. Genet. 107:280-7.

Raboy V, Dickinson DB, 1993. Phytic acid levels in seeds of Glycine max and G. soja as influenced by phosphorus status. Crop Sci. 33:1300-5.

Raboy V, Noaman MM, Taylor GA, Pickett SG, 1991. Grain phytic acid and protein are highly correlated in winter wheat. Crop Sci. 31:631-5.

Rubiales D, 2015. Legumes in Mediterranean agricultures. In: C. Vaz Patto (ed.) Legume perspectives. International Legume Society, Córdoba, Spain, p. 4.

Silva EO, Bracarense APFRL, 2016. Phytic acid: from antinutritional to multiple protection factor of organic systems. J. Food. Sci. 81:R1357-62.

Sparvoli F, Bollini R, Cominelli E, 2015. Nutritional value. In: A.M. De Ron (ed.) Grain legumes. Handbook of plant breeding. Springer, New York, NY, USA, pp. 291-325.

Sparvoli F, Laureati M, Pilu R, Pagliarini E, Toschi I, Giuberti G, Fortunati P, Daminati MG, Cominelli E, Bollini R, 2016. Exploitation of common bean flours with low antinutrient content for making nutritionally enhanced biscuits. Front. Plant Sci. 7:928.

Vucenik I, Shamsuddin AM, 2006. Protection against cancer by dietary $\mathrm{IP}_{6}$ and inositol. Nutr. Cancer 55:109-25. 